\title{
Peran Digital On-Line [DO] dalam Pengadaan yang Berkeadilan Sosial bagi Seluruh Rakyat Indonesia
}

\author{
Junaedi Mulawardana ${ }^{\text {a* }}$ \\ ${ }^{a}$ Lembaga Ilmu Pengetahuan Indonesia (LIPI), Jakarta, Indonesia
}

INFORMASI ARTIKEL

Article history:

Dikirim tanggal: 19 November 2019

Revisi pertama tanggal: 04 Agustus 2020

Diterima tanggal: 07 Agustus 2020

Tersedia online tanggal: 19 Agustus 2020

Keywords: Digital On-Line (DO), procurement, synergy, ordering party

\section{ABSTRACT}

Procurement in government synergy is one of the activities that plays an important role in the running of a Ministry, Institution and Regional Government. When a procurement process is hampered, it is certain that activities on Ministry, Institution and Regional Government will be affected, both in terms of budget absorption and the output. In the procurement activities there are many factors that cause the procurement process to not run as it should, it can be caused by technical and nontechnical constraints. Evaluation of rules and methods of change is one solution to minimize it. On-line procurement methods are the right solution to conduct procurement that is efficient, effective, transparent, open, competitive, fair and accountable. Because this will cut the direct relationship between the buyer with the provider, So the results of this procurement process will be utilized by the Indonesian people both directly and indirectly as users of the results of all procurement processes carried out by Ministry, Institution and Regional Government.

\section{INTISARI}

Pengadaan dalam sinergi pemerintahan merupakan salah satu kegiatan yang memegang peran penting berjalannya suatu Kementerian, Lembaga dan Pemerintah Daerah (K/L/PD). Ketika suatu proses pengadaan terhambat, maka bisa dipastikan kegiatan pada K/L/PD akan terkena dampaknya, baik secara serapan anggaran maupun output kegiatannya. Dalam kegiatan pengadaan banyak sekali faktor yang menyebabkan proses pengadaan tidak dapat berjalan sesuai dengan semestinya, baik kendala teknis maupun non teknis. Evaluasi aturan dan perubahan metode pengadaan adalah salah satu solusi dalam meminimalisir kendala teknis dan non teknis. Metode pengadaan yang dilakukan secara on-line adalah solusi tepat untuk melakukan pengadaan yang efisien, efektif, transparan, terbuka, bersaing, adil dan akuntabel. Karena ini akan memangkas interaksi secara langsung antara pemesan barang/ jasa dengan penyedia. Sehingga hasil dari proses pengadaan tersebut akan dapat termanfaatkan oleh masyarakat Indonesia baik secara langsung maupun tidak langsung sebagai enduser dari hasil semua proses pengadaan yang dilakukan pada $\mathrm{K} / \mathrm{L} / \mathrm{PD}$. 


\section{Pendahuluan}

Hakikatnya semua masyarakat Indonesia mempunyai hak sama untuk hidup, mendapatkan manfaat dari ilmu pengetahuan, penghidupan yang layak, mendapatkan pekerjaan, dan mendapatkan pendidikan. Hal diatas sudah diatur dalam UUD 1945 Amandemen - pada pasal 28 A yang berbunyi "Setiap orang berhak untuk hidup serta berhak mempertahankan hidup dan kehidupannya". Kemudian juga terdapat pada Pasal $28 \mathrm{C}$ ayat 1 yang berbunyi:

Setiap orang berhak mengembangkan diri melalui kebutuhan dasarnya, berhak mendapat pendidikan dan memperoleh manfaat dari ilmu pengetahuan dan teknologi, seni dan budaya demi meningkatkan kualitas hidupnya dan demi kesejahteraan umat manusia.

Dan terdapat pula pada Pasal 27 ayat 2 yang berbunyi:

Tiap-tiap warga negara berhak atas pekerjaan dan penghidupan yang layak bagi kemanusiaan.

Untuk mewujudkan hal-hal diatas pemerintah melalui kementerian, lembaga dan pemerintah daerah melaksanakan program-program kegiatan yang disusun secara efektif dan efisien agar output dan sasarannya sesuai dengan target yang telah ditetapkan. Dalam melaksanakan program-program diatas pemerintah melibatkan masyarakat, ini direalisasikan dengan tetap mengutamakan UMKM dalam pelaksanaan programprogram kegiatannya. Hal ini tertuang dalam Perpres 16 Tahun 2018 pada bagian "Menimbang" yang berbunyi:

Bahwa untuk mewujudkan Pengadaan Barang/ Jasa Pemerintah sebagaimana dimaksud pada huruf a, perlu pengaturan Pengadaan Barang/ Jasa yang memberikan pemenuhan nilai manfaat yang sebesar-besarnya (value for money) dan kontribusi dalam peningkatan penggunaan produk dalam negeri, peningkatan peran usaha Mikro, Usaha kecil dan Usaha menengah serta pembangunan berkelanjutan.

Pasal 4 pada point $\mathrm{c}$ disebutkan bahwa "Pengadaan Barang/Jasa bertujuan untuk: meningkatkan peran serta Usaha Mikro, Usaha Kecil dan Usaha Menengah.”. Selanjutnya poin d berbunyi "Meningkatkan peran pelaku Nasional". Serta poin g berbunyi" Mendorong pemerataan ekonomi".

Jika kita melihat dari peraturan yang disusun oleh pemerintah diatas, jelas bahwa pengadaan barang/ jasa ditujukan untuk kemaslahatan bangsa indonesia, ini dimulai dari hulu pada proses penyusunan kegiatan tiaptiap K/L/PD, proses pelaksanaan pengadaan, pemanfaatan barang/ jasa hasil pengadaan oleh K/L/PD dan terakhir goal pemanfaatan pengadaan tersebut yang digunakan untuk melayani rakyat Indonesia sebagai enduser dari semua proses pengadaan barang/ jasa. Setiap proses tahapan diatas diharapkan memberikan manfaat pada masing-masing pelaku yang berperan pada setiap tahapan yang dilakukan. Tujuan secara makro dari pengadaan barang/ jasa seperti tersebut diatas dapat tercapai jika semua pelaku pengadaan barang/ jasa melaksanakan sesuai dengan aturan pengadaan yang disertai dengan rasa integritas tinggi untuk kemajuan bangsa dan negara dengan tidak mengutamakan kepentingan pribadi maupun golongan.

\section{Teori}

Digital Online terdiri dari dua suku kata dimana kata tersebut memiliki definisi masing-masing. Definisi Digital menurut Rolnicki (2008) adalah kata, gambar dan grafis yang mendeskripsikan dalam bentuk numeris melalui piranti komputer. Sedangkan Lev Monovich (2002) yang dikutip oleh Aji (2016); mengidentifikasi lima karakteristik digital, yakni numerik representasi, modularitas (prinsip perakitan unit yang lebih besar dari yang lebih kecil), otomatisasi, variabilitas, dan transcoding (hubungan antara komputasi dan budaya sehari-hari). Digital adalah sebuah metode yang kompleks, dan fleksibel yang membuatnya menjadi sesuatu yang pokok dalam kehidupan manusia. Sedangkan Teori Digital adalah sebuah konsep pemahaman dari perkembangan zaman mengenai teknologi dan sains, dari semua yang bersifat manual menjadi otomatis, dan dari semua yang bersifat rumit menjadi ringkas. Dengan Teknologi Digital semua pekerjaan akan dilakukan secara otomatis dengan sistem komputerisasi. Teknologi digital dapat menyimpan/ merekam banyak informasi (data) dengan lebih sedikit media daripada teknologi manual atau analog.

Definisi online menurut Kurniawan \& Java Creativity (2010) adalah sebuah kegiatan yang menggunakan fasilitas jaringan internet untuk melakukan segala kegiatan. Selain itu menurut John, M. Echols \& Shadily (2005) dalam kamus Inggris Indonesia; kata online terdiri dari dua suku kata, yaitu on mengandung arti sedang berlangsung. Sedangkan line berarti garis, barisan, macam, tali, saluran, jalan, batas, deretan, dan tema. Jika kita merujuk pada definisi menurut para ahli diatas dapat kita definisikan bahwa Digital Online adalah suatu kegiatan yang dilakukan menggunakan fasilitas internet dengan menggunakan data yang bisa berbentuk kata, gambar dan grafis melalui piranti komputer.

Kegiatan online saat ini sudah menjadi perilaku baru bagi para konsumen dalam mencari/ memenuhi kebutuhan hidupnya. Salah satu manfaat dari kegiatan online adalah belanja online (e-commerce). Menurut Kalakota, R., \& Whinston, A.B. (1997), E-Commerce adalah suatu cara bagi seorang konsumen untuk dapat membeli barang yang diinginkan secara online melalui jaringan internet. Menurut Cowles et al., (2002) seperti dikutip Handayani (2010, p.11); ada tiga elemen berbeda yang ditemui dalam e-commerce, yaitu sebagai berikut: 
a) Vendor, yakni organisasi atau orang yang menjual barang atau jasa secara elektronik. Mereka disebut electronic vendor atau $e$-vendor.;

b) Konsumen yang menggunakan jasa elektronik untuk mencari informasi, memesan jasa atau membeli produk; dan

c) Teknologi berupa perangkat keras (komputer, internet, telepon seluler), perangkat lunak yang dapat digunakan untuk bertransaksi.

Ketiga elemen diatas akan selalu saling berinteraksi ketika kita melakukan proses $e$-commerce.

\section{Metode Penelitian}

Pendekatan penelitian ini menggunakan pendekatan yuridis normatif, yaitu suatu pendekatan penelitian yang mengacu pada peraturan dan perundang-undangan yang berlaku yang terkait dengan subyek penelitian. Dimana penulis akan menelaah aturan perundang-undangan yang berhubungan dengan topik penelitian. Selain itu penulis juga akan melakukan studi komparasi dengan Denmark (negara dengan indek persepsi korupsi yang tertinggi Tahun 2018) yang sudah mapan peran digital online dan sistem pengadaannya untuk melihat apakah sistem tersebut bisa diadopsi untuk diimplementasikan di Indonesia.

\section{Hasil Penelitian dan Pembahasan}

Setiap aturan maupun prosedur pada sistem pengadaan selalu dirancang dengan mempertimbangkan tujuan dan prinsip pengadaan. Sebagaimana tujuan tersebut secara umum terdiri dari antara lain sebagai berikut:

a) Menghasilkan barang/ jasa yang tepat dari setiap uang yang dibelanjakan, diukur dari aspek kualitas, jumlah,waktu, biaya, lokasi, dan penyedia;

b) Meningkatkan penggunaan produk dalam negeri;

c) Meningkatkan peran serta Usaha Mikro, Usaha Kecil, dan Usaha Menengah;

d) Meningkatkan peran pelaku usaha nasional;

e) Mendukung pelaksanaan penelitian dan pemanfaatan barang/ jasa hasil penelitian;

f) Meningkatkan keikutsertaan industri kreatif;

g) Mendorong pemerataan ekonomi; dan

h) Mendorong Pengadaan Berkelanjutan.

Prinsip pengadaan sebagaimana tertulis dalam keppres maupun perpres yang terdiri dari: Efisien, Efektif, Transparan, Terbuka, Bersaing, Adil dan Akuntabel. Tujuan dari pengadaan diatas akan tercapai jika para pelaku pengadaan saling berkomitmen untuk melaksanakan proses pengadaan sesuai dengan prinsipprinsip pengadaan. Pada tataran implementasi tidak semua proses pengadaan sesuai dengan apa yang yang diharapkan. Banyak penyimpangan-penyimpangan terjadi pada proses pengadaan baik yang disengaja maupun tidak. Penyimpangan yang tidak disengaja disebabkan karena ketidakpahaman para pelaku pengadaan terhadap prosedur ataupun aturan pengadaan yang sesuai dengan keppres, perpres maupun rujukan aturan pengadaan yang lain (misalnya peraturan menteri -permen-). Sedangkan penyimpangan yang disengaja disebabkan sudah adanya tujuan atau niat dari para pelaku pengadaan untuk memperoleh/ mendapatkan "sesuatu" dari proses pengadaan. Sebagai mana yang telah dipetakan Alfian (2015), potensi terjadinya kecurangan pada proses pengadaan barang/ jasa dapat terjadi pada tahapan (a) perencanaan pengadaan, (b) pembentukan panitia pengadaan atau penunjukan pejabat pengadaan, (c) penetapan sistem pengadaan, (d) penyusunan jadwal pelaksanaan pengadaan, (e) penyusunan perhitungan harga perkiraan sendiri (HPS), (f) penyusunan dokumen pengadaan barang dan jasa, (g) pengumuman dan pendaftaran peserta pelelangan, (h) tahap kualifikasi penyedia barang/ jasa dan pengambilan dokumen penyedia barang/ jasa, (i) penjelasan lelang/aanwijzing, (j) penyampaian dan pembukaan dokumen penawaran, (k) evaluasi penawaran, (l) pembuktian kualifikasi dan pembuatan berita acara hasil pelelangan, $(\mathrm{m})$ penetapan dan pengumuman pemenang lelang, (n) sanggahan peserta lelang dan pengaduan masyarakat, (o) penandatanganan dan pelaksanaan kontrak serta (p) penyerahan barang/ jasa dan pembayaran pekerjaan. Setiap tahapan diatas akan besar potensi kecurangannya jika dilakukan secara interaksi langsung antara para pelaku pengadaan. Jika flashback pada aturan Keppres 80 Tahun 2003 dimana pelelangan umum cukup diumumkan melalui media masa dan papan pengumuman resmi untuk masyarakat umum, maka disini bisa kita lihat sangat besar potensi kecurangan yang bisa dilakukan. Dari sisi Non Penyedia (PA/KPA, PPK, PP) dapat melakukan kecurangan dengan cara mengumumkan pada media masa dengan segmentasi tertentu, dengan posisi dan ukuran iklan yang mempunyai tingkat dimensi, legibility, dan readability rendah, sehingga masyarakat umum tidak mendapatkan informasi yang proporsional ketika ada pelelangan umum pada suatu kementerian, lembaga ataupun pemerintah daerah. Begitu juga pengumuman pada papan pengumuman resmi, para pihak non penyedia dapat melakukan kecurangan dengan hanya mengumumkan dengan waktu yang sangat singkat, begitu sudah dilakukan dokumentasi sebagai bukti telah diumumkan (biasanya dilakukan denga cara mem-foto pengumuman pada papan pengumuman $\mathrm{K} / \mathrm{L} / \mathrm{PD}$ ), maka pengumuman tersebut akan diturunkan dari papan pengumuman. Keppres No. 80 Tahun 2003 sebenarnya sudah mengatur pengadaan yang diumumkan melalui internet, tetapi hal tersebut dilakukan untuk opsi ke-3 yaitu pemilihan langsung jika metode pelelangan umum dan lelang terbatas dirasa secara biaya tidak efisien. Metode pemilihan langsung ini dilakukan dengan dengan 
membandingkan sebanyak-banyaknya penawaran, sekurang-kurangnya tiga penawaran dari penyedia barang/ jasa yang telah lulus pra-kualifikasi serta dilakukan negosiasi baik teknis maupun biaya serta harus diumumkan minimal melalui papan pengumuman resmi untuk penerangan umum dan bila memungkinkan melalui internet. Disini dapat dilihat bahwa internet tidak wajib hukumnya ketika digunakan sebagai media untuk mengumumkan akan adanya pengadaan. Itupun hanya sebagai alternatif media. Jika kita membandingkan Indek Persepsi Korupsi (IPK) Indonesia di Tahun 2002 dengan Tahun 2004, maka akan terlihat perubahan peringkat dan IPK tidak terlalu signifikan. Pada Tahun 2002 IPK Indonesia 1.9 (dengan skala penilaian 1-10), posisi kita berada diperingkat 96 dengan peringkat terendah diposisi 102 adalah Bangladesh. Sedangkan Tahun 2004 posisi kita berada pada peringkat 133 dengan peringkat terendah di 145. IPK Indonesia di Tahun 2004 adalah 2.0, posisi kita setara dengan Angola, Congo, Pantai Gading,Georgia, Tajikistan dan Turmeknistan. Kita hanya bergeser 0,1 dari IPK Tahun 2002 dengan nilai 1.9 menjadi 2.0 di Tahun 2004. Keppres 80 Tahun 2003 sudah disahkan dan diimplementasikan, tetapi masih belum ada perubahan kearah positif terkait dengan persoalan pengurangan aktivitas korupsi. Menurut analisa penulis salah satu faktor penyebab tidak adanya perubahan yang lebih baik terkait dengan persoalan pencegahan tindak pidana korupsi adalah belum ditetapkannya media internet secara wajib sebagai media untuk proses pengadaan barang/ jasa. Padahal pada Tahun 2003 teknologi internet sudah cukup mampu secara teknis digunakan sebagai media untuk dilakukannya proses pengadaan barang/ jasa. Teknologi internet pada Tahun 2003 sudah sampai pada Enhanced Data Rates for GSM Evolution (EDGE) yang mempunyai kecepatan data sebesar $384 \mathrm{kbps}$. Ini bisa digunakan pada proses pengadaan barang/ jasa asalkan tidak memerlukan data streaming.

Tabel 1 Peringkat dan IPK Indonesia dari Tahun 2000 s.d Tahun 2018

\begin{tabular}{|l|c|c|c|c|}
\hline No. & Tahun & Peringkat & $\begin{array}{c}\text { (Indek } \\
\text { Persepsi } \\
\text { Korupsi) } \\
\text { IPK }\end{array}$ & $\begin{array}{c}\text { Total Jumlah } \\
\text { Negara yang } \\
\text { dinilai }\end{array}$ \\
\hline 1 & 2000 & 85 & 1,7 & 90 \\
\hline 2 & 2001 & 88 & 1,9 & 92 \\
\hline 3 & 2002 & 96 & 1,9 & 102 \\
\hline \multicolumn{5}{|c|}{ Keppres 80 Tahun 2003 disahkan } \\
\hline 4 & 2003 & 122 & 1,9 & 133 \\
\hline 5 & 2004 & 133 & 2,0 & 145 \\
\hline 6 & 2005 & 137 & 2,2 & 158 \\
\hline 7 & 2006 & 130 & 2,4 & 163 \\
\hline 8 & 2007 & 143 & 2,3 & 179 \\
\hline 9 & 2008 & 126 & 2,6 & 180 \\
\hline 10 & 2009 & 111 & 2,8 & 180 \\
\hline \multicolumn{5}{|c|}{ Perpres 54 Tahun 2010 disahkan } \\
\hline 11 & 2010 & 110 & 2,8 & 178 \\
\hline
\end{tabular}

\begin{tabular}{|c|c|c|c|c|}
\hline No. & Tahun & Peringkat & $\begin{array}{c}\text { (Indek } \\
\text { Persepsi } \\
\text { Korupsi) } \\
\text { IPK }\end{array}$ & $\begin{array}{c}\text { Total Jumlah } \\
\text { Negara yang } \\
\text { dinilai }\end{array}$ \\
\hline 12 & 2011 & 100 & 3.0 & 182 \\
\hline 13 & 2012 & 118 & 32 & 173 \\
\hline 14 & 2013 & 114 & 32 & 175 \\
\hline 15 & 2014 & 107 & 34 & 174 \\
\hline 16 & 2015 & 88 & 36 & 167 \\
\hline 17 & 2016 & 90 & 37 & 176 \\
\hline 18 & 2017 & 96 & 37 & 180 \\
\hline 19 & 2018 & 89 & 38 & 180 \\
\hline$K e t e r g a n$ & & & \\
\hline
\end{tabular}

Keterangan:
- Tahun 2000 s.d 2011 skala penilaian yang digunakan adalah 1-10 (Skala $0 \rightarrow$ Sangat Korup, 10 $\rightarrow$ Sangat bersih)

- Tahun 2012 s.d 2018 skala penilaian berubah menjadi dari $1-100$ (Skala $0 \rightarrow$ Sangat Korup, 100 $\rightarrow$ Sangat bersih)

Sumber: Transparency, 2019

Untuk mengetahui perkembangan peringkat Indonesia terhadap jumlah negara yang dinilai, penulis mengelompokkan peringkat menjadi empat kwadran, dimana kwadran I berisi peringkat/ posisi negara dengan IPK tertinggi sampai dengan $25 \%$, kwadran II berisi posisi negara dengan IPK diatas $25 \%$ sampai dengan $50 \%$, kwadran III berisi posisi negara dengan IPK diatas $50 \%$ sampai dengan $75 \%$ dan kwadran IV berisi posisi negara dengan IPK diatas $75 \%$ sampai dengan yang terendah dari total negara yang dinilai setiap tahunnya.

Tabel 2 Posisi Indonesia pada Kwadran dari Tahun 2000 s.d Tahun 2018

\begin{tabular}{|c|c|c|c|c|c|c|c|}
\hline \multirow{3}{*}{ No } & \multirow{3}{*}{ Th } & \multirow{3}{*}{$\begin{array}{l}\text { Jumlah } \\
\text { Negara } \\
\text { yang } \\
\text { Dinilai }\end{array}$} & \multirow{3}{*}{$\begin{array}{l}\text { Per } \\
\text { ing } \\
\text { kat } \\
\text { Ind } \\
\text { one } \\
\text { sia }\end{array}$} & \multicolumn{4}{|c|}{ Posisi Indonesia } \\
\hline & & & & $\begin{array}{l}\text { Kwa } \\
\text { dran } \\
\text { I }\end{array}$ & $\begin{array}{l}\text { Kwa } \\
\text { dran } \\
\text { II }\end{array}$ & $\begin{array}{l}\text { Kwad } \\
\text { ran III }\end{array}$ & $\begin{array}{l}\text { Kwadr } \\
\text { an IV }\end{array}$ \\
\hline & & & & $\begin{array}{l}\text { Peri } \\
\text { ngka } \\
\text { t }\end{array}$ & $\begin{array}{l}\text { Perin } \\
\text { gkat }\end{array}$ & $\begin{array}{l}\text { Pering } \\
\text { kat }\end{array}$ & $\begin{array}{l}\text { Pering } \\
\text { kat }\end{array}$ \\
\hline 1 & 2000 & 90 & 85 & $1-22$ & $23-45$ & $46-67$ & $68-90$ \\
\hline & & & & & & & $\sqrt{ }$ \\
\hline 2 & 2001 & 92 & 88 & $1-23$ & $24-46$ & $47-69$ & $70-92$ \\
\hline & & & & & & & $\sqrt{ }$ \\
\hline 3 & 2002 & 102 & 96 & $1-25$ & $26-51$ & $52-76$ & $\begin{array}{l}77- \\
102\end{array}$ \\
\hline & & & & & & & $\sqrt{ }$ \\
\hline 4 & 2003 & 133 & 122 & $1-33$ & $34-66$ & $67-99$ & $\begin{array}{l}100- \\
133\end{array}$ \\
\hline & & & & & & & $\sqrt{ }$ \\
\hline 5 & 2004 & 145 & 133 & $1-36$ & $37-72$ & $\begin{array}{l}73- \\
108\end{array}$ & $\begin{array}{l}109- \\
145\end{array}$ \\
\hline & & & & & & & $\sqrt{ }$ \\
\hline
\end{tabular}




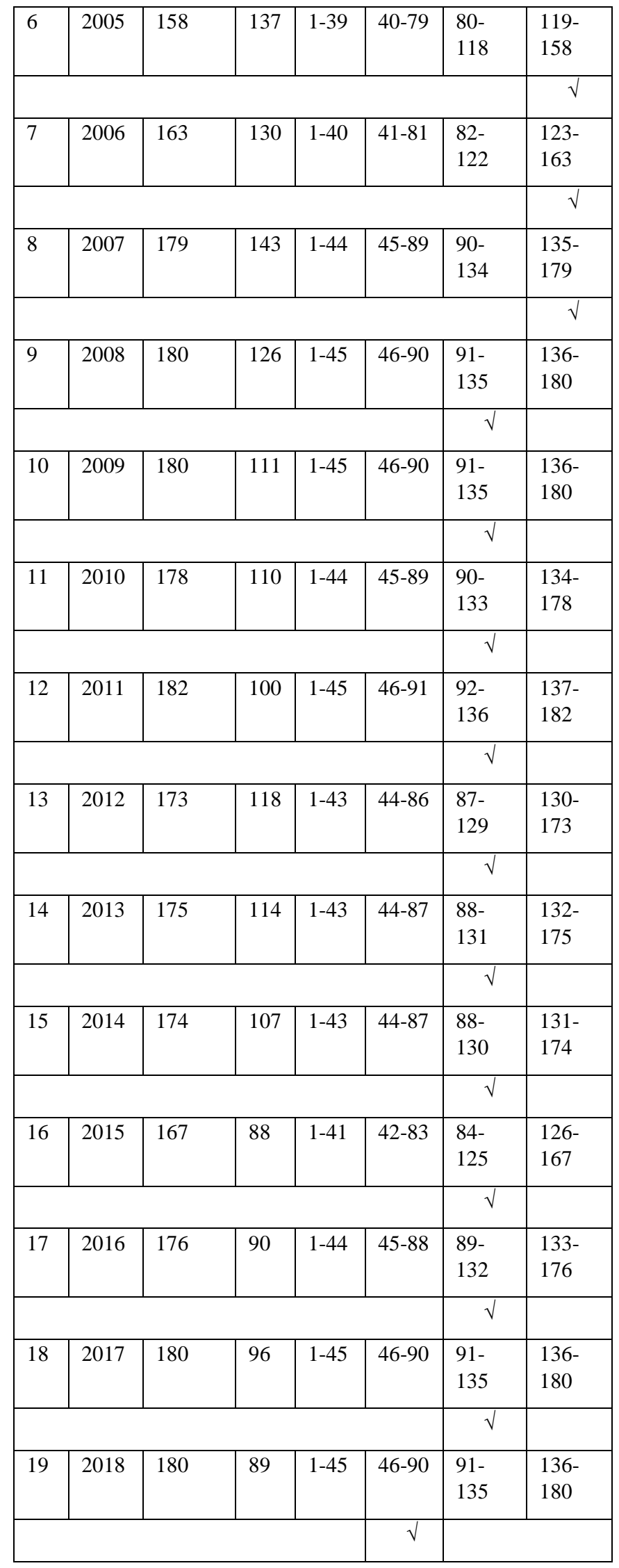

Sumber: Transparency, 2019

Jika melihat daftar pada Tabel 2 diatas, maka posisi Indonesia pada kwadran dari Tahun 2000 s.d 2018 peringkat Indonesia semakin meningkat lebih baik terutama setelah Perpres 54 Tahun 2010 disahkan.
Sebelum Perpres 54 Tahun 2010 disahkan dan dimplementasikan posisi Indonesia rata-rata masuk didalam kwadran 4. Setelah aturan mengenai proses pengadaan barang/ jasa yang harus dilakukan melalui online, maka perlahan tapi pasti peringkat Indonesia semakin bergeser ke posisi/ peringkat yang lebih baik. Ini adalah tonggak sejarah dimana proses pengadaan barang/ jasa di Indonesia wajib dilaksanakan/dilakukan melalui media on-line. Didalam perpres 54 Tahun 2010 terdapat pasal-pasal yang mengatur proses pengadaan barang/ jasa harus dilakukan secara on-line, ini dimulai dari sebelum proses pengadaan dilakukan yaitu dengan mengunggah Rencana Kerja dan Anggaran Kementerian Negara/ Lembaga (RKA-KL) melalui aplikasi Sistem Informasi Rencana Umum Pengadaan (SIRUP) LKPP. Hal ini diatur dalam Pasal 25 ayat 3 yang berbunyi "Pengumuman sebagaimana dimaksud pada ayat (2), dilakukan dalam website $\mathrm{K} / \mathrm{L} / \mathrm{D} / \mathrm{I}$ masing-masing dan papan pengumuman resmi untuk masyarakat serta Portal Pengadaan Nasional melalui LPSE." Dengan diumumkannya RKAKL pada aplikasi SIRUP maka publik akan tahu berapa nilai anggaran pada suatu instansi dalam satu tahun dan mana yang akan bisa menjadi potensi bisnis sesuai dengan Klasifikasi Baku Lapangan Usaha Indonesia (KBLI) yang mereka miliki. Pada tahap pelaksanaan pengadaan barang/ jasa juga harus dilakukan melalui Portal Pengadaan Nasional, yaitu LPSE, ini tidak terbatas pada metode Pelelangan Umum, Pelelangan Sederhana, Pemilihan Langsung, Pengadaan Langsung. LKPP juga telah membuat suatu system pengadaan pembelian/ sewa barang/ jasa dengan menggunakan media on-line, yaitu dengan metode E-Purchasing. Metode ini digunakan untuk melaksanakan proses pengadaan barang/ jasa dengan cara melakukan pembelian barang/ jasa melalui sistem katalog elektronik. Secara teknis ini seperti kita berbelanja ditoko online, jadi cukup pilih barang yang akan kita beli, negosiasi dengan penyedia, jika sudah tercapai kesepakatan dengan penyedia maka paket bisa diteruskan ke PPK untuk meminta persetujuan pembelian. Sistem E-Purchasing bisa dikatakan revolusi dalam sejarah pengadaan barang/ jasa di Indonesia. Pembelian barang, jasa penyewaan tidak dibatasi oleh nilai. Dengan metode e-purchasing bisa dikatakan peluang untuk terjadinya praktek korupsi sangat kecil karena proses negosiasi dilakukan langsung oleh LKPP kepada penyedia barang/ jasa dengan bentuk ikatan kontrak payung dan proses pelaksanaannya dilakukan secara menyeluruh melalui media on-line.

Jika diperhatikan secara seksama metode pengadaan yang ditetapkan dalam Perpres 54 Tahun 2010, maka peran digital secara online sudah mulai terlibat dalam setiap pelaksanaan proses pengadaan barang/ jasa. Kedua hal tersebut bisa menjadi solusi untuk mengurangi praktek korupsi dalam proses pengadaan barang/ jasa. 
Proses digital dan online harus dilakukan secara berkesinambungan agar dapat berfungsi secara efektif. On-line tidak bisa menjadi solusi jika tidak dilakukan proses digital terlebih dahulu. Begitu juga sebaliknya, data digital tidak bisa menjadi solusi jika proses pelaksanaan pengadaan barang/ jasa tidak dilakukan secara online. Untuk mencapai pengadaan barang/ jasa dengan tingkat Korupsi yang rendah ini tidak hanya menjadi tanggung jawab LKPP saja. Secara yuridis memang segala hal yang terkait dengan proses pengadaan barang/ jasa baik itu teknis dan regulasi adalah menjadi tanggung jawab LKPP. Tetapi untuk mencapai tingkat kecurangan agar sangat rendah dalam proses tersebut tetap membutuhkan sinergi dengan institusi, lembaga lain, dan pihak eksekutif selaku penentu kebijakan dalam bentuk regulasi. LKPP sudah melakukan "gebrakan" dengan mengubah proses pengadaan yang awalnya dilakukan secara offline menjadi online. Pencegahan dan tindakan dalam memerangi korupsi tidak bisa dilakukan secara parsial, tetapi harus dilakukan secara komprehensif. Jika Alfian (2015) telah memetakan potensi pengadaan dari sisi Pelaku Pengadaan Non Penyedia ada pada 15 tahapan pengadaan, maka untuk mencegah secara komprehensif perlu adanya peta potensi korupsi dari sisi penyedia baik pada proses yang berkaitan langsung pada proses pengadaan maupun proses yang tidak berkaitan langsung. Salah satu potensi adanya korupsi pada proses pengadaan tidak langsung adalah pada tahapan birokrasi pengurusan izin dalam melakukan kegiatan berusaha. Sebelum adanya Perpres No.91 Tahun 2017 tentang Percepatan Pelaksanaan Berusaha dan Peraturan Pemerintah No. 24 Tahun 2018 tentang Pelayanan Perizinan Berusaha Terintegrasi Secara Elektronik; pengurusan perizinan berusaha masih dilakukan secara terpisah. Setiap instansi atau pihak yang mengeluarkan surat perizinan atau yang terkait dengan administrasi kegiatan berusaha ada potensi kegiatan melakukan korupsi. Ketika ini terjadi maka akan memengaruhi secara tidak langsung dari sisi peminta izin/ penyedia akan adanya potensi melakukan korupsi juga dalam proses pengadaan barang/ jasa, yaitu dengan cara memasukkan biaya-biaya yang dikeluarkan yang tidak sesuai dengan tarif resmi kedalam produk yang akan dipasarkan. Jika penulis petakan maka proses akan adanya potensi korupsi yang berkaitan langsung bisa kelompokkan menjadi tiga tahapan, sebagai berikut:

Tabel 3 Tiga Tahap Proses Adanya Potensi Korupsi yang Berkaitan dengan Pengadaan

\begin{tabular}{|c|c|c|}
\hline I & \multicolumn{2}{|c|}{ Tahapan Pra Dipa } \\
\hline \multicolumn{2}{|c|}{ Aktivitas } & Potensi Bentuk Korupsi \\
\hline 1 & $\begin{array}{lr}\text { Pengenalan/ } \\
\text { penawaran } \\
\text { produk } & \text { yang } \\
\text { dilakukan } & \text { secara } \\
\text { tatap } & \text { muka } \\
\text { langsung } & \text { antara }\end{array}$ & $\begin{array}{l}\text { Adanya kesepakatan yang } \\
\text { dilakukan oleh pihak penyedia } \\
\text { dan non penyedia. }\end{array}$ \\
\hline
\end{tabular}

\begin{tabular}{|c|c|c|}
\hline & $\begin{array}{l}\text { pihak penyedia } \\
\text { dan non penyedia. }\end{array}$ & \\
\hline 2 & $\begin{array}{l}\text { Penyusunan } \\
\text { proposal kegiatan. }\end{array}$ & $\begin{array}{l}\text { Adanya kesepakatan antara non } \\
\text { penyedia dengan penyedia. }\end{array}$ \\
\hline II & \multicolumn{2}{|c|}{ Tahapan Pelaksanaan DIPA } \\
\hline \multicolumn{2}{|c|}{ Aktivitas } & Potensi Bentuk Korupsi \\
\hline 1 & $\begin{array}{l}\text { Perencanaan } \\
\text { pengadaan }\end{array}$ & $\begin{array}{l}\text { Kesepakatan dengan penyedia } \\
\text { terkait dengan waktu yang } \\
\text { memudahkan pihak penyedia } \\
\text { tertentu. }\end{array}$ \\
\hline 2 & $\begin{array}{l}\text { Penetapan sistem } \\
\text { pengadaan }\end{array}$ & $\begin{array}{l}\text { Kesepakatan dengan penyedia } \\
\text { terkait dengan system } \\
\text { pengadaan yang memudahkan } \\
\text { penyedia tertentu. }\end{array}$ \\
\hline 3 & $\begin{array}{l}\text { Penyusunan } \\
\text { perhitungan harga } \\
\text { perkiraan sendiri } \\
\text { (HPS) }\end{array}$ & $\begin{array}{l}\text { Kesepakatan dengan pihak } \\
\text { penyedia terkait dengan nilai } \\
\text { HPS yang mengikuti } \\
\text { ketersediaan barang pada } \\
\text { penyedia, bukan berdasarkan } \\
\text { kebutuhan. }\end{array}$ \\
\hline 4 & $\begin{array}{l}\text { Pengumuman dan } \\
\text { pendaftaran } \\
\text { peserta } \\
\text { pelelangan, }\end{array}$ & \begin{tabular}{lrr}
\multicolumn{3}{l}{ Waktu pengumuman di setting } \\
sedemikian rupa r untuk \\
memudahkan & pihak-pihak \\
tertentu. &
\end{tabular} \\
\hline 5 & $\begin{array}{l}\text { Tahap kualifikasi } \\
\text { penyedia } \\
\text { barang/jasa dan } \\
\text { pengambilan } \\
\text { dokumen } \\
\text { penyedia } \\
\text { barang/jasa, }\end{array}$ & $\begin{array}{lr}\text { Kebutuhan } & \text { barang/jasa } \\
\text { disesuaikan dengan } & \text { kualifikasi } \\
\text { penyedia tertentu. } & \end{array}$ \\
\hline 6 & $\begin{array}{l}\text { Penyampaian dan } \\
\text { pembukaan } \\
\text { dokumen }\end{array}$ & $\begin{array}{l}\text { Waktu penyampaian dokumen } \\
\text { disesuaikan untuk memudahkan } \\
\text { penyedia tertentu. }\end{array}$ \\
\hline 7 & $\begin{array}{l}\text { Evaluasi } \\
\text { penawaran, }\end{array}$ & $\begin{array}{l}\text { Evaluasi penawaran } \\
\text { memudahkan pihak tertentu. } \\
\text { Dimana pihak tersebut sudah } \\
\text { membuat kesepakatan dengan } \\
\text { non penyedia. }\end{array}$ \\
\hline 8 & $\begin{array}{l}\text { Pembuktian } \\
\text { kualifikasi dan } \\
\text { pembuatan berita } \\
\text { acara } \\
\text { pelelangan, }\end{array}$ & $\begin{array}{l}\text { Pembuktian kualifikasi } \\
\text { memudahkan pihak tertentu . }\end{array}$ \\
\hline III & \multicolumn{2}{|c|}{ Tahapan Pasca DIPA } \\
\hline 1 & $\begin{array}{l}\text { Pengenalan/pena } \\
\text { waran produk } \\
\text { yang dilakukan } \\
\text { secara tatap muka } \\
\text { langsung antara } \\
\text { pihak penyedia } \\
\text { dan non penyedia. }\end{array}$ & $\begin{array}{l}\text { Adanya Kesepakatan yang } \\
\text { dilakukan oleh pihak penyedia } \\
\text { dan non penyedia. }\end{array}$ \\
\hline 2 & $\begin{array}{l}\text { Penyusunan } \\
\text { kegiatan yang } \\
\text { akan dilakukan } \\
\text { untuk tahun depan }\end{array}$ & $\begin{array}{l}\text { Adanya Kesepakatan yang } \\
\text { dilakukan oleh pihak penyedia } \\
\text { dan non penyedia, terkait dengan } \\
\text { supply barang/jasa kegiatan } \\
\text { yang akan dilakukan tahun } \\
\text { depan. }\end{array}$ \\
\hline
\end{tabular}

Sumber: Hasil analisis, 2019

Sedangkan potensi korupsi pada proses yang tidak langsung berkaitan dengan pengadaan dapat dipetakan sebagai berikut: 
Tabel 4 Potensi Korupsi pada Proses yang Tidak Langsung Berkaitan dengan Pengadaan

\begin{tabular}{|c|c|c|}
\hline \multicolumn{2}{|r|}{ Aktivitas } & Potensi Bentuk Korupsi \\
\hline 1 & $\begin{array}{lr}\text { Informasi } & \text { terkait } \\
\text { dengan } & \text { aturan, } \\
\text { prosedur, biaya/tarif } & \text { terhadap } \\
\text { layanan } & \text { terhanarak } \\
\text { masyarakatum } \\
\text { semuanya } & \text { bisa } \\
\text { diakses secara online }\end{array}$ & $\begin{array}{l}\text { Adanya "permainan" dari } \\
\text { pihak pemberi layanan } \\
\text { untuk memberikan biaya } \\
\text { jasa tambahan diluar tarif } \\
\text { resmi, karena pihak } \\
\text { pengguna layanan tidak } \\
\text { mengetahui informasi } \\
\text { sacara pasti terkait aturan, } \\
\text { prosedur dan tarif resmi } \\
\text { layanan }\end{array}$ \\
\hline 2 & $\begin{array}{l}\text { Pengurusan perizinan } \\
\text { berusaha yang tidak } \\
\text { terintegrasi dan satu } \\
\text { atap. Setiap surat } \\
\text { perizinan dikeluarkan } \\
\text { oleh instansi yang } \\
\text { berbeda dengan tidak } \\
\text { ada standar biaya, } \\
\text { waktu dan dilakukan } \\
\text { secara offline }\end{array}$ & $\begin{array}{l}\text { - Permintaan biaya } \\
\text { tambahan agar proses } \\
\text { penyelesaian perizinan } \\
\text { bisa lebih cepat } \\
\text { terselesaikan. } \\
\text { - Budaya "Pemberian } \\
\text { Imbalan" yang tidak tepat } \\
\text { kepada petugas yang } \\
\text { notabene memang sudah } \\
\text { menjadi tugasnya }\end{array}$ \\
\hline 3 & $\begin{array}{l}\text { Penyimpanan Data } \\
\text { Base warga negara } \\
\text { yang belum terpusat } \\
\text { dan tidak dilakukan } \\
\text { secara online }\end{array}$ & $\begin{array}{l}\text { Manipulasi identitas atau } \\
\text { terbitnya identitas ganda } \\
\text { yang dapat digunakan untuk } \\
\text { tujuan tertentu yang tidak } \\
\text { sesuai aturan atau undang- } \\
\text { undang yang berlaku }\end{array}$ \\
\hline 4 & $\begin{array}{lr}\text { Belum } & \text { seluruhnya } \\
\text { layanan } & \text { pemerintah } \\
\text { kepada } & \text { masyarakat } \\
\text { dapat } & \text { dilakukan } \\
\text { secara online }\end{array}$ & $\begin{array}{l}\text { Layanan secara offline } \\
\text { rawan akan terjadinya } \\
\text { kesepakatan yang tidak } \\
\text { resmi antara pemberi } \\
\text { layanan dan pengguna } \\
\text { layanan, karena dalam } \\
\text { proses ini kedua belah pihak } \\
\text { beratap muka secara } \\
\text { langsung }\end{array}$ \\
\hline 5 & $\begin{array}{lr}\text { Belum } & \text { seluruhnya } \\
\text { proses } & \text { pembayaran } \\
\text { kepada } & \text { pemerintah } \\
\text { dilakukan } & \text { secara } \\
\text { online } & \end{array}$ & $\begin{array}{l}\text { Proses pembayaran secara } \\
\text { offline rawan akan adanya } \\
\text { cashback dan timbulnya } \\
\text { Budaya "Pemberian } \\
\text { Imbalan" yang tidak tepat } \\
\text { kepada petugas yang } \\
\text { notabene memang sudah } \\
\text { menjadi tugasnya }\end{array}$ \\
\hline
\end{tabular}

Sumber: Hasil analisis, 2019

Potensi korupsi pada proses langsung dan tidak langsung pengadaan barang dan jasa dapat diminimalkan dengan memaksimalkan peran Digital Online [DO] secara konsisten. Beberapa aksi yang sudah dilakukan pemerintah dengan menggunakan Digital Online, antara lain sebagai berikut:

a) Layanan pemerintah sudah mulai diarahkan untuk dilakukan secara online, yaitu sebagai berikut:

- Perizinan berusaha sudah dapat dilakukan melalui www.oss.go.id/oss/
- Proses Pengadaan Barang Jasa dilakukan melalui Layanan Pengadaan Secara Elektronik

b) Program Sistem Identitas Tunggal (e-ktp), ini bertujuan sebagai pusat data terpadu bagi setiap warga negara untuk menghindari terjadinya double identitas yang dapat digunakan untuk tujuan tertentu yang tidak sesuai dengan peraturan dan undang-undang yang berlaku.

c) Penggunaan kartu kredit pemerintah dalam transaksi keuangan yang dibiayai dengan mekanisme uang persediaan.

Dengan dimulainya kebijakan pemerintah untuk semakin menggunakan Digital Online pada semua layanannya maka secara tidak langsung ini akan mendorong Indonesia akan semakin bersih dari korupsi. Kedepan penggunaan data digital online harus menjadi prioritas.

Jika melihat Denmark sebagai negara dengan Indek Persepsi Korupsi tertinggi di Tahun 2018 dengan nilai 88 dari 100, salah satu faktor penyebabnya adalah kebijakan pemerintah Denmark untuk memaksimalkan penggunaan layanan pemerintah melalui media online. Baik untuk proses yang tidak berkaitan langsung dengan pengadaaan dan yang berkaitan langsung dengan pengadaan barang jasa. Ini membutuhkan upaya dan komitmen tinggi. Pemerintah Denmark memulai proses digital sejak Tahun 1968 dengan memperkenalkan CPR-Register yang berisi database informasi tentang data setiap individu yang tinggal di Denmark. Setiap individu yang tinggal di Denmark minimal tiga bulan atau lebih maka wajib lapor kepada pemerintah kota untuk mendapatkan izin tinggal. Setelah izin tinggal terbit maka individu tersebut akan memperoleh $C P R$-Number yang hanya bisa diambil secara langsung oleh pemilik CPR-Number tersebut. Terkait dengan proses yang tidak berkaitan langsung ada lima hal besar yang telah dilakukan pemerintah Denmark terhadap proses digitalisasi online, yaitu: a) Digital Signature, b) Easy Account, 3) Digital ID, 4) Citizen.dk dan 5) Digital Post; yang dapat dijelaskan yaitu sebagai berikut:

a) Digital Signature adalah tanda tangan digital yang sudah mempunyai payung hukum. Sejak 1 Oktober 2001 pemerintah Denmark sudah melegalkan penggunaan tanda tangan digital untuk layanan sektor publik dan bisnis;

b) Easy Account adalah rekening pribadi yang harus/ wajib dimiliki oleh setiap individu (warga negara) dan perusahaan di Denmark. Segala bentuk transaksi keuangan dari pemerintah seperti Pengembalian pajak, dana pensiun, subsidi, biaya siswa dan sebagainya akan ditransfer langsung ke rekening ini. Begitu juga dengan segala transaksi dari sektor privat seperti gaji, asuransi dan sebagainya juga harus melalui rekening ini. Segala bentuk transaksi keuangan dimaksimalkan untuk dilakukan secara cashless. Secara legalitas Easy Account telah 
memiliki payung hukum, yaitu Undang-undang tentang Public Payment No. 1203 tanggal 27 Desember 2003;

c) Digital ID adalah Akun tunggal sebagai pengganti dari Digital Signature. Sejak Tahun 2010 dengan pertimbangan kemudahan penggunaan, kecepatan dan keamanan dalam transaksi peran Digital Signature digantikan oleh Digital ID (NemID). NemID ini terdiri dari User ID, Password, dan Code Card (kartu kode) yang berisi kode yang digunakan setelah user memasukkan User ID dan password. Kartu kode ini hanya berlaku untuk sekali transaksi. Ketika sudah log-out dan akan log-in kembali maka user akan diminta memasukkan kartu kode kembali. Merupakan suatu kewajiban bagi setiap individu di Denmark untuk memiliki NemID ketika bertransaksi untuk layanan perbangkan, bisnis, transaksi dan komunikasi dengan pihak pemerintah;

d) Citizen.dk adalah situs resmi dari Pemerintah Denmark yang berisi layanan pemerintah dari semua sector publik kepada masyarakat. Dalam situs ini semua layanan pemerintah terintegrasi dalam satu situs. Dari sisi pengguna ini sangat memudahkan user untuk mengakses sesuai dengan kebutuhannya, user cukup login sekali menggunakan NemID untuk mendapatkan layanan dari instansi yang berbeda; dan

e) Digital Post adalah email yang wajib dimiliki oleh setiap pelaku bisnis dan warga negara Denmark yang berusia diatas 15 tahun ketika berkomunikasi dengan sektor publik. Secara legalitas segala sesuatu yang dikomunikasikan melalui Digital Post mempunyai kekuatan hukum yang sama seperti dengan dokumen yang dicap dan ditandatangani diatas kertas. Untuk login ke Digital Post user cukup memasukkan NemID.

Sedangkan untuk proses yang berkaitan langsung dengan pengadaan barang jasa pemerintah Denmark melalui Kementerian Industri, Bisnis, dan Keuangan membuat website khusus untuk proses pengadaan, yaitu www.udbud.dk. Arsitektur website tersebut sangat user friendly. Di home page akan ditampilkan menu informasi mengenai Type of procedure, Contract type, Authority type, Full text search dan Place of delivery; yang dapat disorot dan pilih sesuai dengan kebutuhan penyedia dalam melakukan proses pengadaan.

Semua proses pengadaan yang terkait dengan pemerintah terintegrasi langsung melalui website tersebut. Kontrol terhadap proses pengadaan juga tidak hanya dilakukan oleh pemerintah, melalui www.opentender.eu kita juga bisa melaporkan jika ada indikasi korupsi dan juga memperoleh data statistik terkait dengan proses pengadaan.

Pemerintah Denmark sangat komit untuk mewujudkan Good and Clean Government. Segala hal komunikasi dan transaksi yang melibatkan pemerintah dengan masyarakat dilakukan secara online, sehingga historisnya ter-record. Disini terlihat bahwa pencegahan tidak korupsi sudah dilakukan secara komprehensif baik pada proses yang tidak berkaitan langsung dengan pengadaan dan yang berkaitan langsung dengan pengadaan.

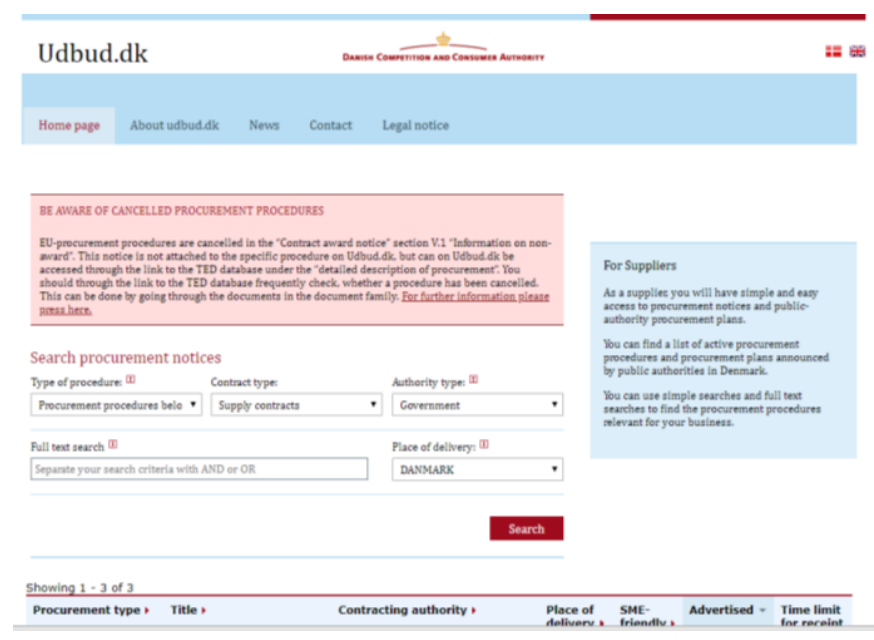

Gambar 1 Interface Website Pengadaan Pemerintah Denmark

Sumber: Udbud, 2019

\section{Kesimpulan}

Bebas korupsi untuk mewujudkan pengadaan yang berkeadilan sosial bukan hanya tanggung jawab LKPP dan KPK semata sebagai wakil dari pemerintah. Upaya tersebut memerlukan usaha yang besar dari semua pihak baik dari pemerintah dan masyarakat. Definisi korupsi menurut Undang-undang No.31 Tahun 1999 adalah setiap orang yang dikategorikan melawan hukum, melakukan perbuatan memperkaya diri sendiri, menguntungkan diri sendiri atau orang lain atau suatu korporasi, menyalahgunakan kewenangan maupun kesempatan atau sarana yang ada padanya karena jabatan atau kedudukan yang dapat merugikan keuangan negara atau perekonomian negara. Menurut Abdullah Hehamahua (2012) korupsi adalah kejahatan luar biasa (extraordinary crime). Ada tiga hal yang membuat korupsi dikategorikan sebagai kejahatan luar biasa, yaitu sebagai berikut:

a) Korupsi di Indonesia sifatnya transnasional. Melakukan korupsi di Indonesia, uangnya dikirim/ disimpan di negara lain;

b) Pembuktian tindak kejahatan korupsi di Indonesia sangat super. Membutuhkan effort yang luar biasa besar untuk bisa membuktikan seseorang terjerat kasus korupsi; dan

c) Dampak korupsi sangat luar biasa. Negara harus menanggung hutang yang luar biasa besar dikarenakan banyak para kepala daerah dan pejabat negara yang melakukan korupsi. Dimana uang 
tersebut seharusnya dipergunakan untuk kepentingan masyarakat Indonesia.

Jika melihat definisi dan pendapat Abdullah Hehamahua (2012) tersebut, maka jelas korupsi merupakan suatu tindak kejahatan luar biasa yang dampaknya bisa dirasakan langsung oleh masyarakat Indonesia. Pengadaan yang berkeadilan sosial adalah pengadaan yang seharusnya bermanfaat bagi masyarakat Indonesia yang dimulai dari proses awal pengadaan sampai dengan hasil akhir pengadaan itu dan juga manfaat secara makro dari hasil pengadaan itu sendiri bagi masyarakat Indonesia. Analoginya adalah jika suatu lembaga penelitian mempunyai program penelitian untuk menemukan varietas jagung unggul yang bisa dipanen sepuluh kali dalam satu tahun dan mempunyai kandungan gizi tinggi untuk kecerdasan otak, untuk ini peneliti membutuhkan microscope bagi kebutuhan risetnya, maka hendaknya proses pengadaan ini disusun sesuai dengan kebutuhannya. Jika microscope bisa dipenuhi oleh UMKM penyedia lokal baik secara teknis dan nilai maka hendaknya diprioritaskan untuk penyedia lokal, jika tidak baru dieskalasi untuk penyedia non kecil. Semua proses harus dilakukan mengikuti prinsip dan tujuan pengadaan barang jasa. Jika barang sudah diterima maka si pengguna microscope dalam hal ini peneliti harus bisa mempertanggungjawabkan hasil penelitiannya agar bisa menghasilkan varietas jagung unggul tersebut. Dimana hasil dari riset tersebut jika dimanfaatkan oleh petani jagung bisa menambah nilai ekonomi bagi petani tersebut dan juga masyarakat Indonesia yang mengkonsumsinya. Dari sisi peneliti secara tupoksinya dia sudah melakukan penelitian dengan tujuan menemukan varietas jagung unggul yang bisa dipanen lebih cepat dari jagung biasa tetapi dengan kandungan gizi yang lebih tinggi, sehingga akan memberikan manfaat ekonomis bagi petani jagung dan meningkatkan kecerdasan otak bagi yang mengkonsumsinya. Dari sisi pelaku pengadaan ini akan membuat "hati menjadi tenang" karena tidak ada manipulasi dan rekayasa dalam proses pelaksanaannya baik dari harga dan proses penentuan metode pengadaannya. Secara ekonomi penyedia mendapatkan keuntungan yang wajar sehingga tidak ada potensi temuan dalam audit nanti.

Kesimpulan yang dapat diambil dari tulisan ini adalah bahwa korupsi adalah kejahatan luar biasa yang penanganannya tidak hanya bisa dilakukan oleh pemerintah saja, semua pihak harus terlibat untuk memberantas korupsi baik dari pemerintah dan masyarakat. Beberapa saran penulis terkait dengan pengadaan yang berkeadilan sosial, adalah sebagai berikut:

a) Segera maksimalkan penggunaan e-ktp untuk menuju Sistem Identitas Tunggal;

b) Layanan pemerintah kepada masyarakat hendaknya segera dimaksimalkan menggunakan media online baik itu yang terkait dengan persoalan pengadaan barang jasa maupun layanan umum personal dan bisnis misalnya pembuatan/ perpanjangan SIM/ STNK, pembayaran pajak, bea cukai, perizinan berusaha dan sebagainya;

c) Interface website layanan publik hendaknya user friendly dengan sistem navigasi yang mudah tetapi tidak mengurangi substansi konten website tersebut; dan

d) Inisiasi penggunaan e-mail sebagai media korespondensi resmi antara pemerintah dengan publik yang dipayungi secara hukum.

\section{Daftar Pustaka}

Aji, Rustam. (2016). Digitalisasi, Era Tantangan Media (Analisis Kritis Kesiapan Fakultas Dakwah Dan Komunikasi Menyongsong Era Digital). Islamic Communication Journal, 1(1), 43-54.

Alfian. (2015). Pemetaan Jenis dan Risiko Kecurangan dalam Audit Pengadaan Barang dan Jasa. Jurnal Pengadaan, 4(1), 1-19.

Echols, John M., \& Hassan Shadily. (2005). Kamus Inggris-Indonesia (Cetakan Kedua). Jakarta: PT. Gramedia Pustaka Utama.

Handayani, Tri. (2010). Analisis Pengaruh Kepercayaan Konsumen terhadap Persepsi Resiko Belanja Online di Surabaya. Skripsi, Fakultas Ekonomi, Sekolah Tinggi Ilmu Ekonomi Perbanas, Surabaya.

Kalakota, R., \& Whinston, A.B. (1997). Electronic commerce - A manager's guide. Massachusetts: Addison-Wesley Longman.

Kurniawan, Dedik., \& Java Creativity. (2010). Kupas Tuntas Bisnis dan Penghasilan Online (Cetakan Pertama). Jakarta: Elex Media Komputindo.

Ramadhani, Mutia., \& Muhaimin, Ramdhan. (2012, Februari 23). Inilah 3 Alasan Mengapa Korupsi Disebut Kejahatan Luar Biasa. Republika.co.id. Diakses dari https://www.republika.co.id/berita/nasional/huku $\mathrm{m} / 12 / 02 / 23 /$ ztpqj-inilah-3-alasan-mengapakorupsi-disebut-kejahatan-luar-biasa.

Rolnicki, Tom E. (2008). Pengantar Dasar Jurnalisme (Scolastic Journalism). Jakarta: Prenada Media.

Transparency. (2019). Corruption Perceptions Index. Diakses 26 Agustus 2019, dari https://www.transparency.org/en/cpi/2018.

Udbud. (2019). Danish Competition and Consumer Authority. Diakses 11 September 2019, dari https://www.udbud.dk/ 